\title{
Co to jest medium?
}

\section{KRZYSZTOF KOZŁOWSKI}

Kariera, którą w ostatnich dziesięcioleciach zrobiło pojęcie medium, otoczone nierzadko aurą swoistej euforii i mitu[1], sprawiła, iż w języku potocznym zatarła się niemal całkowicie granica między metaforycznym a dosłownym znaczeniem tego pojęcia. Coraz częściej słyszy się o medium sztuki, literatury, muzyki, miłości, pieniądza, teatru lub filmu, tak jakby nie istniała tutaj zasadnicza, wynikająca z natury poszczególnych zjawisk, odmienność terminologiczna i bytowa. Ponieważ samo słowo stało się synonimem czegoś nobilitującego (zapewne nie bez związku z mass mediami), nie brakuje głosów, że medium może okazać się wszystko i że najbardziej oczywistym tudzież dostępnym człowiekowi medium jest „medium języka”. W uzasadnieniu takiego poglądu powraca przekonanie o kryjących się w języku, a poświadczonych kulturowo możliwościach komunikacyjnych.

Oczywiście, niepodobna utrzymywać, jakoby język nie był podstawowym narzędziem komunikacyjnym, ale ten, kto widzi w nim zarazem medium, zdaje się całkowicie lekceważyć proste, poświadczone empirycznie, rozróżnienie medioznawcze między komunikacją bezpośrednią a pośrednią. Zapomina o tym, iż mówienie jest procesem zakorzenionym w ludzkich organach, zachodzącym wewnątrz konkretnego ciała, słowem, że jest artykulacją („nie znam - pisał Thrasybulos G. Georgiades w Nennen und Erklingen nie bez wyraźnej ironii - języka «w głębszym sensie»"[2]). I że wszelka komunikacja medialna jest z natury rzeczy komunikacją pośrednią, zakładającą istnienie nośników (kanałów), które są powszechnie akceptowane, acz kulturowo zmienne. O ile można zatem powiedzieć o człowieku, iż mowa stanowi o jego istocie, o tyle zupełnie bezsensowne byłoby podstawienie w miejsce mowy pojęcia medium i wysunięcie twierdzenia, że to właśnie ono przesądza o byciu człowiekiem. Jak wielka jest różnica między głosem ludzkim jako instrumentem a innymi instrumentami muzycznymi, widać najlepiej na przykładzie opartej na fundamencie osobowym muzyki wokalnej (przez wiele wieków utożsamianej z muzyką jako taką, czego praktyczną i teoretyczną kulminacją były kompozycje a cappella Giovanniego Pierluigiego da Palestriny[3]).

Błędne jest zarazem traktowanie za Marshallem McLuhanem mediów jako przedłużeń człowieka[4]. Także tutaj zakres poję-

[1] W. Faulstich, Einführung in die Medienwissenschaft. Probleme-Methoden - Domänen, München 2002, s. 26 i n.

[2] Th.G. Georgiades, Nennen und Erklingen. Die Zeit als Logos, aus dem Nachlaß hrsg. von I. Bengen, mit einem Geleitwort von H.-G. Gadamer, Göttingen 1985, s. 5. Jednocześnie Georgiades podkreśla, że przekonanie, iż „[...] można wiedzieć więcej, niż pozwalają na to granice ludzkiej natury, prowadzi do pychy (hybris). Zasięg ludzkiego pojmowania jest jak promień jakiejś sfery, w której jesteśmy zamknięci. Sfera ta nie jest jednak ciemnym więzieniem, w którym może się, stąpając po omacku, poruszać wyłącznie pozytywistyczna ścisła nauka" (ibidem, s. 18). Wszystkie tłumaczenia cytatów obcojęzycznych - jeśli nie zaznaczono inaczej - pochodzą ode mnie - K.K. [3] Palestrina, jeśli spojrzeć na niego z punktu widzenia tradycji umuzyczniania mszy, nie tylko wyznaczył koniec epoki karolińskiej, lecz także wszedł w nowe czasy. Jak dodaje Georgiades, „wypełnił on to, co było jeszcze dotąd otwartym żądaniem, i skierował tym samym duchowe stawanie się muzyki na nowe tory". Th.G. Georgiades, Musik und Sprache. Das Werden der abendländischen Musik dargestellt an der Vertonung der Messe, Berlin-Heidelberg-New York 19742, s. 43. [4] „Analizę źródeł i rozwoju poszczególnych przedłużeń człowieka - postulował McLuhan powinno poprzedzić przyjrzenie się ogólnym 
cia medium jest zbyt szeroki[5]. Miast cokolwiek wyjaśniać, rozumowanie to zaciemnia najbardziej podstawowe wymiary znaczenia pojęcia medium. Największym jego mankamentem jest wszakże utożsamianie medium z niezwykłym narzędziem, instrumentem lub wielkim wynalazkiem. Bo też - dla przykładu - uznanie pisma za medium doprowadziło do sytuacji paradoksalnej: to, co wchodziło w skład wielu mediów i co nie może zaistnieć bez ich pośrednictwa w przestrzeni komunikacyjnej (z mediów pisanych wymieńmy przede wszystkim książkę, czasopismo, gazetę, zwój lub ścianę[6]), pojmuje się jako coś autonomicznego właśnie pod względem medialnym. „A przecież - jak zauważa trafnie Werner Faulstich - samo pismo nie jest medium, lecz stanowi powszechny instrument, zakrojo-

aspektom środków przekazu, czyli przedłużeń człowieka, poczynając od nigdy wcześniej niezgłębianego odrętwienia, jakie każde $\mathrm{z}$ tych przedłużeń wywołuje u jednostki i w społeczeństwie”. M. McLuhan, Zrozumieć media. Przedłużenia człowieka, wprowadzenie L.H. Laphama, przeł. N. Szczucka, Warszawa 2004, s. 35. Dieter Mersch (Teorie mediów, przeł. E. Krauss, Warszawa 2010, s. 109-110), podążając tym tropem, zauważa, co następuje: „McLuhanowska antropologia mediów nie podaje definicji pojęcia mediów zorientowanego na jakieś określone cechy czy warunki. Media pojmowane są w niej jako rozszerzenia ludzkiego ciała i ludzkich zmysłów, takie jak ubranie, instrumenty, okulary, rower czy też książki, żarówki, gazety i telewizja. [...] Tak jak techniki w ogóle albo wszystkie ludzkie artefakty, media są protezami. Tym twierdzeniem McLuhan nawiązuje do wczesnej filozofii techniki Ernsta Kappa [...], ucznia Hegla, który nazywał broń i narzędzia przedłużeniami ludzkich organów. Kapp ze swej strony nawiązywał do antropologicznych koncepcji człowieka jako istoty ułomnej, które można prześledzić w filozofii od Herdera do Nietzschego".

[5] Werner Faulstich podkreśla, że Understanding Media stanowią wyjątkowo dziwaczną mieszaninę elementów. Znaleźć tu można: (a) „cytaty z aktualnych tekstów prasowych", (b) anegdoty z (c) cytatami zaczerpniętymi z naukowej literatury przedmiotowej praktycznie wszystkich dyscyplin, (d) „przeplatane Biblią cytaty z literackich ny na szeroką skalę system znaków, który umożliwia tylko abstrakcyjne zapisywanie; ono samo staje się tym, czym jest, dopiero dzięki medium. Są media bez pisma, ale nie ma pisma bez medium. I naturalnie istniały także kultury bez pisma i istnieją kultury obrazu - jak dzisiaj - bez pisma"[7]. To samo zastrzeżenie choć trzeba znowu dodać: dla przykładu jedynie - odnosi się do literatury, jako że od niepamiętnych czasów posługiwała się ona rozmaitymi mediami, przechodząc wraz z nimi kolejne fazy (media ludzkie, pisane, drukowane, analogowe, cyfrowe), a medium książki stało się w jej wypadku tak wielką oczywistością [8], iż do dziś - mimo licznych badań nad kulturą oralną i jej sposobami przechowywania tudzież wykonywania „literatury” [9] - bywa $\mathrm{z}$ nim wcale często identyfikowane.

klasyków, takich jak Szekspir, James Joyce, Milton albo Yeats”, (e) „ciemne metafory”, (f) więcej niż 20 rozmaitych pojęć mediów, prowadzących do intelektualnego zamętu i (g) wysoce niezrozumiałe, ale uczenie brzmiące wypowiedzi. W. Faulstich, Einführung in die Medienwissenschaft..., s. 21.

[6] Zob. W. Faulstich i C. Rückert,

Mediengeschichte in tabellarischem Überblick von den Anfängen bis heute (Teil I und Teil II),

Bardowick 1993 („IfAM-Arbeitsberichte”, t. 8). [7] W. Faulstich, Mediengeschichte von den Anfängen bis 1700, Göttingen 2006, s. 36.

[8] Książka - mimo iż zaliczana bywa zawsze do grupy mediów pisanych i drukowanych - powstała dopiero w II wieku n.e. i wywodzi się bezpośrednio z kodeksu, który składał się pierwotnie z pojedynczych, poskładanych i przyciętych kart pergaminowych, zaopatrzonych później w twardy grzbiet. W przeciwieństwie do dawnych mediów pisanych kodeks nadawał się w szczególności do dłuższych tekstów. Kulturowo preferowany był przede wszystkim przez chrześcijan, którzy chcieli odróżnić się od judaizmu i właściwej dla niego, wszechobecnej estetyki zwoju. Jak przekonuje Faulstich, „W czasach prześladowania kodeks pozwalał się łatwiej ukryć niż wielkie nieporęczne zwoje. Był bardziej praktyczny w podróżach misyjnych chrześcijańskich kaznodziejów”. W. Faulstich, Mediengeschichte von den Anfängen..., s. 69-70. Na jednoznacznie genetyczny związek nowego medium kodeksu $\mathrm{z}$ literaturą wczesnochrześcijańską zwrócił uwagę Gerd Theißen, 
W refleksji nad tym, czym jest medium i jak należy je definiować, nader rzadko mówi się o mediach ludzkich, a przecież to właśnie zaliczane do tej grupy media, szeroko rozpowszechnione we wszystkich kulturach tradycyjnych i wysoko rozwiniętych, trzeba uznać za najstarsze w historii ludzkości[10]. Były one najbardziej rozpowszechnione w kulturach starożytnych i wiązały się ściśle $\mathrm{z}$ funkcjami społecznymi, jakie pełnili poszczególni ludzie. Tak jak nie każdy mógł być szamanem w społeczności tradycyjnej[11], tak też jedynie dla tych ludzi, którym powierzano ważne stanowiska lub funkcje w systemie społecznym, rezerwowano zaszczytne miano medium. Za przykład powinien wystarczyć tu kapłan w starożytnym Egipcie[12] lub błazen w kulturze średniowiecznej Europy. Ten ostatni -

uwypuklając jej ludowy, acz powszechny charakter. „Dla wykształconych na klasycznej estetyce nowotestamentowe pisma - wywodził w Die Entstehung des Neuen Testaments als literaturgeschichtliches Problem - zostały napisane w stylu prostych ludzi, należały one do sermo humilis. Nowotestamentowe pisma były w ich oczach często niekulturalne, prostackie i niezdarne. Jeśli abstrahować od klasycznej estetyki, łatwo pojąć, że mogły one oddziaływać szeroko, irytująco i przemożnie. Wnosiły wtedy nie tylko nowy ton, lecz także nowe medium: dopiero we wczesnochrześcijańskiej literaturze kodeks zastąpił pisane zwoje. Kodeks był formą książki dla praktycznych potrzeb dnia codziennego, a nie jedynie dla wysokiej literatury. Wszystkie chrześcijańskie rękopisy były od razu przeznaczone dla kodeksów. Nieliczne wyjątki pozwalają się częściowo objaśnić jako ćwiczenia. Tym samym chrześcijanie przeprowadzili małą rewolucję: codzienne formy użytkowe kodeksu stały się nośnikami najbardziej wartościowych tekstów. Prachrześcijańska literatura jest piśmiennictwem małego ruchu, który był zakorzeniony w niskich warstwach społecznych, ale już wcześniej przyciągnął ludzi z warstw wyższych i stworzył im warunki, by mogli wywrzeć swój wpływ". G. Theißen, Die Entstehung des Neuen Testaments als literatur-geschichtliches Problem, Heidelberg 2007, s. 349-350 („Schriften der Philosophisch-historischen Klasse der Heidelberger Akademie der Wissenschaften", t. 40). Zob. też W. Faulstich, Das Medium als Kult. Von przykładowo - pełnił zasadniczo trzy funkcje[13], przynajmniej aż do czasu, gdy został zdegradowany. Po pierwsze, przysługiwała mu pozycja żartownisia, jawił się więc jako medium rozrywki (opowiadał zabawne historie, konfabulował, śpiewał pieśni, trudnił się zadawaniem zagadek, mienił się mimem i akrobatą, klownem, a nawet muzykiem); po drugie, był synonimem statusu majątkowego panujących. Znaczyło to, że nosił drogie szaty i był przyzwoicie opłacany. Ponieważ widziano w nim zwierciadło zatrudniającego go władcy, funkcjonował jak fasada mieszczańskiego domu. Po trzecie, pełnił funkcję pośrednika i funkcja ta była też w jego wypadku najważniejsza. Błazen pośredniczył wewnątrz zamku, przekazując różnego rodzaju wiadomości, ale zarazem mediował między Kościołem a pań-

den Anfängen bis zur Spätantike (8. Jahrhundert), Göttingen 1997, s. 255 („Die Geschichte der Medien", t. 1).

[9] Zob. E.A. Havelock, Muza uczy się pisać. Rozważania o oralności i piśmienności w kulturze Zachodu, przekład i wstęp P. Majewski, Warszawa 2006, s. 73-81; W.J. Ong, Oralność i piśmienność. Stowo poddane technologii, przeł. i wstępem opatrzył J. Japola, Lublin 1992, s. 25-54; A.B. Lord, Pieśniarz i jego opowieść, przekład P. Majewski, red. naukowa G. Godlewski, Warszawa 2010, s. 61 in.

[10] Zob. W. Faulstich, Das Medium als Kult..., s. 293-299 (294).

[11] Na temat rekrutacji szamanów i powołania mistycznego zob. M. Eliade, Szamanizm i archaiczne techniki ekstazy, przeł. i wstępem opatrzył K. Kocjan, naukowo opracował J. Tulisow, Warszawa 1994, s. 15-44.

[12] „Właściwością tożsamościowej teokracji pisze Jan Assmann (Ägypten. Eine Sinngeschichte, Frankfurt am Main 1996, s. 333) - jest to, że panuje sam bóg, innymi słowy: miejsce władcy pozostaje niezajęte. Kapłana, który de facto sprawuje władzę, pojmuje się jako sługę i otrzymującego od boga polecenia. Jeśli jednak kapłan występuje jako przedstawiciel boga jako władcy, to lepiej mówić o teokracji reprezentowanej”. Zob. też W. Faulstich, Das Medium als Kult..., s. $162-167$.

[13] Zob. W. Faulstich, Mediengeschichte von den Anfängen bis 1700, s. 83-84. 
stwem. Jak przekonuje Faulstich, „mógł powiedzieć księciu, co myślą o nim inni, a czego nikt inny nie ważyłby się zrobić. [...] Był więc kanałem komunikacyjnym w obu kierunkach, rodzajem medium informacyjnego i kontroli [...]"[14].

W tym samym paradygmacie mieści się też teatr, który jest dzisiaj ostatnim żywotnym medium ludzkim. Przez teatr jako medium należy rozumieć określoną sytuację międzyludzką, która - wykorzystując i „inscenizując” ludzkie „naprzeciwko”[15] - wytwarza analogię do realnego życia. I tutaj komunikacja ma charakter poniekąd „bezpośredni”, różnica w stosunku do rzeczywistości jako takiej polega jednak na tym, że jest to wyłącznie realność „scenicznego" przedstawienia człowieka. Wszelkie próby zatarcia granicy między

[14] Ibidem, s. 84. Szerzej na ten błazna jako medium zob. W. Faulstich, Medien und Öffentlichkeiten im Mittelalter (800-1400), Göttingen 1996, s. 52-69 („Die Geschichte der Medien”, t. 2).

[15] Th.G. Georgiades, Das musikalische Theater, w: Kleine Schriften, Tutzing 1977, s. 133 („,Münchner Veröffentlichungen zur Musikgeschichte", t. 26). [16] Jak pisze Faulstich w odniesieniu do XVIII wieku, „książka stała się nośnikiem i pośrednikiem kompleksowych tekstów literackich, stała się medium literatury. Wraz z powstającym rynkiem książki wykształciło się jednocześnie sześć instancji mieszczańskiej komunikacji książkowej, które funkcjonują w zasadzie do dzisiaj: autor, wydawca, księgarz, krytyk, bibliotekarz, czytelnik. Pozytywny obraz książki opierał się na pozytywnym obrazie literatury, czytelnika i literackiego wykształcenia. Rzekomo «podwójna natura» książki («tu duch, tam towar») znalazła w tej epoce swe uzasadnienie". W. Faulstich, Die Theorie des Buches, w: Vom eigensinn des Buches. Warum schnelle Zeiten langsame Medien brauchen?, hrsg. von J.-F. Huffmann \& A. Röper, Berlin 2010, s. 73-74. Prestiż książki jako nośnika wartości zaczął podupadać wraz z pojawieniem się w XIX wieku społeczeństw industrialnych i masowych, które w istotny sposób książkę zdemokratyzowały. Egalitaryzacja książki, która się wtedy dokonała, a w XX wieku osiągnęła punkt szczytowy, sprawiła, że charakteryzujące to medium „możliwości dokonań" uległy pewnemu osłabieniu (książka jako prezent). W konsekwencji - słusznie lub nie życiem a teatrem nie mogą zmienić faktu, iż - chcąc zaprzeczyć klasycznie pojętej teorii teatru - trzeba wyjść od właściwej samemu teatrowi umowności i przynajmniej na początku podjętego eksperymentu myślowego starać się ją zakwestionować. W praktyce znaczy to tyle, co potwierdzić mimowolnie jej intuicyjnie odczuwaną pierwotność.

O znaczeniu teatru jako medium dobre pojęcie może dać przede wszystkim jego długa historia. Wiek XVIII i XIX to wprawdzie czasy panowania w Europie medium książki[16], a następnie - po epoce oświecenia - medium gazety, we wszystkich ich odmianach kulturowych i odcieniach wydawniczych (szczególnie wyraźnie widać to w odniesieniu do dziewiętnastowiecznej gazety ilustrowanej), ale obejmujący różnorodne formy arty-

- przeniesiono na nią w większym stopniu niż do tej pory funkcje pozostałych mediów drukowanych, analogowych czy cyfrowych o znaczącym stopniu dominacji: informacyjność (kartka, fotografia, telefon lub gazeta), pluralistyczność (czasopismo, telewizja, radio, nośnik dźwięku), niezależność czasowo-przestrzenną (fotografia, list, radio, $\mathrm{CD}$ lub iPod), zdolność do rozwiązywania problemów (World Wide Web), introwertyczność (list, Intranet), trudność w użytkowaniu (komputer lub specjalistyczne czasopisma), etc. Zob. ibidem, s. 75.

[17] Zob. D. Borchmeyer, Das Theater Richard Wagners. Idee - Dichtung - Wirkung, Stuttgart 1983, s. 19-39.

[18] Werner Faulstich, który opisał teatr na przestrzeni wieków z medioznawczego punktu widzenia, poczynając od czasów najdawniejszych, poprzez starożytność, średniowiecze i nowożytność, a kończąc na czasach najnowszych, dowiódł, iż przemiany, dokonujące się w „systemie” mediów każdej epoki, wpływają na inne jego „upozycjonowanie”. Wynika to przede wszystkim $\mathrm{z}$ faktu, że dominacja poszczególnego medium lub grupy mediów oznacza podporzadkowanie sobie pozostałych bądź też całkowitą lub przynajmniej częściową ich koherencję. Stopniowe zanikanie albo nagłe przewartościowanie znaczącej pozycji danego medium w systemie mediów prowadzi do przejmowania jego funkcji przez media konkurencyjne albo nowej generacji. I tak rozwój mediów drukowanych i ich coraz 
styczne teatr pozostawał dla obydwu mediów godnym konkurentem (tak iż Richard Wagner, planując społeczną rewolucję, mógł się zwrócić w stronę teatru operowego[17]). Obok sztuk wybitnych, niekwestionowanych wydarzeń artystycznych, funkcjonowały dzieła świadczące głównie o żywotności samego medium. $Z$ tego też względu historyczna ocena tych ostatnich nie będzie nigdy w pełni rzeczowa, jeśli pominie się całkowicie medialny aspekt sztuki teatru.

Zmiany, które dokonały się w systemie mediów na przełomie XIX i XX wieku (film i pozostałe media analogowe), sprawiły, iż starając się odróżnić teatr od innych mediów lub sztuk i literatury, artyści teatru podjęli wysiłek znalezienia dlań nowego miejsca, co było zresztą zgodne $\mathrm{z}$ funkcjonowaniem systemu

bardziej zaznaczająca się pozycja sprawiły, że jakkolwiek teatr nie przekształcił się - podobnie jak inne media ludzkie XVII wieku - w konfederację zawodów, to jednak zapewnił sobie osobne miejsce, które do dziś gwarantuje mu status medium, nawet jeśli status ten jest poważnie ograniczony. „Wzrastająca dominacja nowych mediów drukowanych, resp. kultury literackiej - pisze Faulstich - oznaczała mianowicie fundamentalną dewaluację starych mediów ludzkich, resp. kultury oralnej, tj. dewaluację cielesności jako środka kształtującego i wyrażającego. Ta dewaluacja nie była jednak dla teatru całkowitym odwartościowaniem medium, chociaż stracił on społeczną dominację. Teatr pozostał raczej medium niszowym, aż do dzisiaj”. W. Faulstich, Medien zwischen Herrschaft und Revolte. Die Medienkultur der frühen Neuzeit (1400-1700), Göttingen 1998, s. 293 („Die Geschichte der Medien”, t. 3). Na pytanie o przyczyny tego stanu rzeczy Faulstich odpowiada, że trzeba ich szukać w funkcji teatru, a ściślej mówiąc: $\mathrm{w}$ potrzebie inscenizowania live, które zakłada stałe powtarzanie. Czym dla jednych jest religia i jej rytuały, tym dla drugich teatr, $\mathrm{z}$ jego „przedstawieniem live jako oczyszczeniem skalanej przez zabijanie duszy" (ibidem, s. 294). „Trwanie teatru jako medium, kontynuuje Faulstich, nawet jeśli ograniczone tylko do małych grup ludności, w odniesieniu do zwycięskiego pochodu mediów drukowanych w czasach nowożytnych, tłumaczy wyjątkowość tego, jak konstytuowany jest tutaj [w teatrze - K.K.] sens. Walter mediów w każdej epoce (każdorazowe „upozycjonowanie" jakiegoś medium jest swoistym prawem medialnym[18]). Już tylko krok dzielił tych artystów od nieuniknionego przekształcenia medium teatru w sztukę teatru. Projektowi temu poświęconych było wiele programów reformatorskich, które pozostały aktywne przez cały wiek XX; również dzisiaj nie brakuje ludzi teatru przekonanych o tym, iż jedynie przez nich tworzony teatr jest teatrem we właściwym tego słowa znaczeniu.

W opozycji do tych projektów istnieją instytucje teatralne, starające się zapewnić teatrowi należny mu prestiż i odzyskać stracone terytoria... Zgłaszane przez nie aspiracje są nie tylko potwierdzeniem historycznego statusu samego medium, lecz także dowodem istnienia świadomości systemu, w którym

Houg zauważa przenikliwie: podczas spektaklu w centrum komunikacji z widzem znajduje się prezentacja live, wariacja, inscenizacja, aktualizacja, od dawna znanej i zawsze tej samej sztuki. Celem nie jest jednak nowa konkretna prezentacja, lecz zaledwie potwierdzenie dobrze znanego schematu. Chodzi o wariację, pozwalającą uobecniać zawsze ten sam sens, resp. nieustannie czynić go dostępnym; im więcej powtarzania [konkretnej - K.K.] inscenizacji, tym wyraźniejsze staje się sedno wypowiedzi. Dlatego do natury medium teatru od czasów nowożytnych należy okoliczność, iż chce się ono ograniczyć do porównywalnie ściśle określonego kanonu. Całkiem inaczej jawią się media drukowane, w których to sztuka generuje swój sens poprzez wariację i dwuznaczność, nie kryje się on więcej w tym, co identyczne, lecz $\mathrm{w}$ «tym, co różne» $[. .$.$] . Byłoby rzeczą groteskową$ przepisywać nieustannie jakąś powieść.

To, co teatr jako medium ludzkie komunikuje poprzez aktora, poprzez jego cielesną obecność na scenie, osiągane jest $w$ mediach drukowanych retorycznie: w miejsce nieustannie nowego, innego przedstawienia wchodzi definitywne ożywienie, ze szczególną językową organizacją i narratywnie-inscenizowanymi formami budowy. Innymi słowy, zastąpienie przedstawienia (media ludzkie) sytuacją czytania (media drukowane) oznaczało zupełnie inny sposób konstruowania sensu. Teatr jest posłuszny jeszcze - jako jedyny w swoim rodzaju - «starym» zasadom kultury oralnej" (ibidem, s. 295). 
media funkcjonują. Jeśli jednak jest w ogóle coś do odzyskania, to dlatego, że w wyniku nieuniknionych zmian poniesione zostały jakieś straty.

Dominacja jednego medium oznacza nierzadko pomniejszenie znaczenia pozostałych; a ponieważ refleksja nad mediami jest w gruncie rzeczy refleksją nad historią kultury, medialna historia kultury musi zakładać szeroko pojętą komplementarność podejścia badawczego. Jak twierdzi Faulstich, nie może być ona „historią książki plus historią teatru plus historią telewizji - i tak dalej" [19], lecz powinna oznaczać - pojętą na wskroś holistycznie - „historię wszystkich mediów w ich splocie" [20] i systemowym powiązaniu. Innymi słowy, medioznawcza nauka o kulturze jest - odróżnieniu od dyscyplin szczegółowych - metanauką, którą należy uważać jednak za budulec obejmującego całość kulturoznawstwa, jako że „media stanowią tylko część kultury, zapewne ważną” [21].

Dopiero na takim gruncie możliwa jest odpowiedź na postawione w tytule pytanie. Rzecz jasna, przy założeniu, że wszelka definicja ma wartość wyłącznie operacyjną i że powinna być ona na tyle pojemna, iżby mogła pomieścić najbardziej różnorodne zjawiska. W wypadku mediów jest to zadanie szczególnie utrudnione, zważywszy na rozpiętość badanego materiału, komplikacje terminolo-

[19] W. Faulstich, Das Medium als Kult..., s. 9.

[20] Ibidem.

[21] Ibidem.

[22] W. Faulstich, Medientheorie, w: Grundwissen Medien, hrsg. von W. Faulstich, Paderborn 20045 s. 13-20. Przykładem takich teorii jest choćby teoria Niklasa Luhmanna, dla którego „miłość” jest pojmowanym jako kod medium kulturowym. Zob. N. Luhmann, Semantyka miłości. O kodowaniu intymności, przeł. J. Łoziński, Warszawa 2003. $\mathrm{Na}$ temat polemiki ze stanowiskiem Luhmanna zob. W. Faulstich, Die bürgerliche Mediengesellschaft (1700-1830), Göttingen 2002, s. 113 i n. („Die Geschichte der Medien”, t. 4).

[23] Saxer jest autorem precyzyjnego rozróżnienia literatury od mediów. „«Literatura» jak też «media» - pisał - powinny być rozumiane jako giczne i wielość teorii, które mają często charakter zbyt arbitralny[22]. Najbardziej pojemną, najszerzej rozpowszechnioną i jednocześnie empirycznie w pełni weryfikowalną formułę zaproponował Werner Faulstich, odwołując się do pojęcia medium wypracowanego przez Urlicha Saxera[23]. „Przez medium pisał - należy rozumieć zinstytucjonalizowany system ufundowany wokół zorganizowanego kanału komunikacyjnego o specyficznych możliwościach dokonań i o społecznej dominacji”"[24].

Ponieważ definicja ta wymaga szczegółowego komentarza, Faulstich zatroszczył się o przedstawienie czterech wymiarów jej znaczenia. Po pierwsze, uznał, że „zinstytucjonalizowany system” to tyle, co „kompleksowy, zróżnicowany mechanizm pośredniczący, który wkracza w rozmaite obszary społeczne i oddziałuje na rozmaitych poziomach" [25]. Ale zinstytucjonalizowanie nie musi tutaj oznaczać jakichś wyższych instytucji społecznych, lecz może wiązać się z czymś, co jest rozumiane jako społecznie ugruntowane, a więc „powszechnie znane, przez wielu ludzi użytkowane i jako takie właśnie akceptowane" [26]. Po drugie, Faulstich, nazywając „medium zorganizowanym kanałem komunikacyjnym", przyjmował, iż funkcjonowanie danego medium nie jest nigdy przypadkowe. Przeciwnie, stoi za nim świadoma działalność

«systemy», a mianowicie jako systemy społeczne, to znaczy jako możliwe do odróżnienia ramy ludzkiej działalności. Mogą one tworzyć poza tym instytucje komunikacji [...]. Literatura i książka weszły instytucjonalnie $\mathrm{w}$ tak intensywne relacje, że jeszcze dzisiaj uważa się książkę za literaturę par excellence. Nie wolno jednak dać się zwieść co do tego, że w procesie komunikacji książka - jak każde inne medium - występuje jako kanał, literatura natomiast jako wysoce wyspecjalizowany system znakowy, jako kod". U. Saxer, Literatur in der Medienkonkurrenz, „Media Perspektiven” 1977, nr 12, s. 673-685.

[24] W. Faulstich, Medientheorie, s. 18.

[25] W. Faulstich, Medienwissenschaft, Paderborn 2004, s. 12.

[26] Ibidem. 
człowieka, obejmująca jego aktywność zarówno w dziedzinie techniki, jak i w sferze życia kulturalnego; „możliwe do pomyślenia są przy tym inne formy tworzenia kanałów komunikacyjnych" (ugruntowany rytuał albo konkretna retoryka)[27]. Po trzecie, „specyficzne możliwości dokonań"; oznacza to, że media różnią się między sobą pod względem szczególnych możliwości dokonań, co ma też zawsze charakter ilościowy i jakościowy[28]. „W każdym wypadku - dodaje Faulstich implikuje to odmienne możliwości i granice komunikacyjnego pośredniczenia" [29]. Po czwarte, „społeczna dominacja”, którą trzeba rozpatrywać przede wszystkim w kontekście znaczenia danego medium dla konkretnego społeczeństwa, a nie wyłącznie dla pojedynczego człowieka. Innymi słowy, nie istnieje prywatne medium, i to tym bardziej, że media pozostają w stanie nieustannej rywalizacji. „Jeśli na przykład funkcje jakiegoś konkretnego medium jako systemu zostaną przejęte $\mathrm{w}$ biegu dziejów przez inne media bez uszczerbku, to medium "pierwotne» traci społeczną dominację, a w konsekwencji charakter medium" [30].

Jak można się przekonać, czytając liczne prace niemieckich medioznawców, definicja ta i wszystkie wymiary jej znaczenia pozwoliły na stworzenie historycznej „mapy mediów”, która każe postrzegać media jako „rozwiązujące problemy systemy” (Saxer)[31] i opisywać ich przemiany oraz żywotność, poczynając od najdawniejszych czasów, poprzez średniowiecze, w którym centralnym medium była książka, powiązana ściśle $\mathrm{z}$ ludzkim medium nauczyciela (magister, doktor), aż po współczesność - z jej rewolucją dokonaną poprzez media cyfrowe (komputer, WWW, mail, czat, blog, Intranet / Extranet). „Mapa mediów” daje też sposobność wglądu w najbardziej odległe epoki, a przede wszystkim - oddzielając wyraźnie komunikację pośrednią od komunikacji bezpośredniej i tworząc grupy mediów - w sensowny sposób ogranicza ich liczbę, tak iż łatwo przekonujemy się, że w procesie komunikowania się społeczeństwa dbają głównie o najlepsze kanały komunika- cyjne. Innym walorem ujęcia holistycznego i empirycznego, opartego na myśleniu historycznym, jest oddzielenie sensów dosłownych od metaforycznych, które pozwala w konsekwencji na potoczne posługiwanie się pojęciem medium, tak odległym od ujęcia ściśle medioznawczego[32].

Medioznawstwo znaczy tu jednak już coś innego niż w ujęciu McLuhana, który był wprawdzie niezwykłym wizjonerem i który otworzył nam oczy na wiele spraw dotyczących funkcjonowania mediów, lecz który nie był na pewno naukowcem[33]. Toteż nie będzie przesadą twierdzenie, iż stworzenie empirycznego medioznawstwa oznaczało ni mniej, ni więcej, tylko symboliczne „ojcobójstwo”. Podobnie jak Platon Permenidesa, zmuszone było ono „uśmiercić” McLuhana. Rezultatem tego „przestępstwa” okazało się powstanie metanauki, której zadaniem jest interdyscyplinarne i empiryczne badanie relacji między mediami. Słowem, takie ich opisywanie, które umożliwia nam dzisiaj udzielenie pełniejszej odpowiedzi na pytanie, co to jest medium. Zadziwiające jest tylko to, że w wielu pracach medioznawczych, które nadal nie odróżniają komunikacji pośredniej od komunikacji bezpośredniej, nie pojęto jeszcze przerażających skutków tego zbrodniczego czynu... [34]

[27] Ibidem.

[28] Zob. ibidem.

[29] Ibidem.

[30] Ibidem.

[31] U. Saxer, Medien als problemlösende Systeme, „Spiel” 1991, z. 1, s. 45-79.

[32] Ten w dużym stopniu niepokojący stan rzeczy odnośnie do rozumienia pojęcia medium określa się też niekiedy żartobliwie mianem „sałatki metafor”. Zob. W. Faulstich, Einführung in die Medienwissenschaft..., s. 19.

[33] Ibidem, s. 22.

[34] Przykładem tej zadziwiającej obojętności mogłoby być choćby wprowadzenie do teorii mediów, autorstwa Danieli Kloock i Angeli Spahr. Prezentuje się tu w sposób dowolny tylko te teorie, które odpowiadają z góry przyjętej tezie o „teorii nowych mediów". Zob. D. Kloock i A. Spahr, Medientheorien. Eine Einführung, München 20072. 